\title{
REMOVING AMMONIUM FROM WATER USING MODIFIED CORNCOB-BIOCHAR
}

Thi Mai Vua, Van Tuyen Trinh ${ }^{\mathrm{b}}$, Dinh Phuong Doan', Huu Tap Van', Tien Vinh

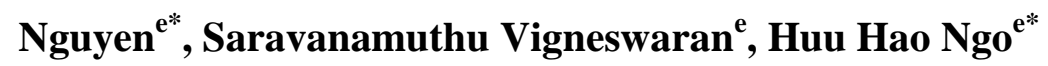

${ }^{a}$ Hanoi University of Natural Resources and Environment, Ministry of Natural Resources and Environment, 44 Phu Dien, Tu Niem, Ha Noi, Viet Nam

${ }^{b}$ Institute of Environmental Technology, Vietnam Academy of Science and Technology, A30, 18 Hoang Quoc Viet Street, Ha Noi, Viet Nam

${ }^{c}$ Institute of Materials Science, Vietnam Academy of Science and Technology, 18 Hoang Quoc Viet Street, Ha Noi, Viet Nam

${ }^{d}$ Faculty of Environment and Earth Science, Thai Nguyen University of Sciences, Tan Thinh ward, Thai Nguyen city, Viet Nam

${ }^{e}$ Faculty of Engineering and IT, University of Technology, Sydney (UTS), PO Box 123, Broadway, Sydney, Australia

* Corresponding author:

Huu Hao Ngo, Tel: 61-295142745, Fax: 61-2-95147803, Email: HuuHao.Ngo@uts.edu.au Tien Vinh Nguyen, Tel: 61-295142620, Fax: 61-2-95147803, Email: Tien.Nguyen@uts.edu.au 


\section{GRAPHICAL ABSTRACT}
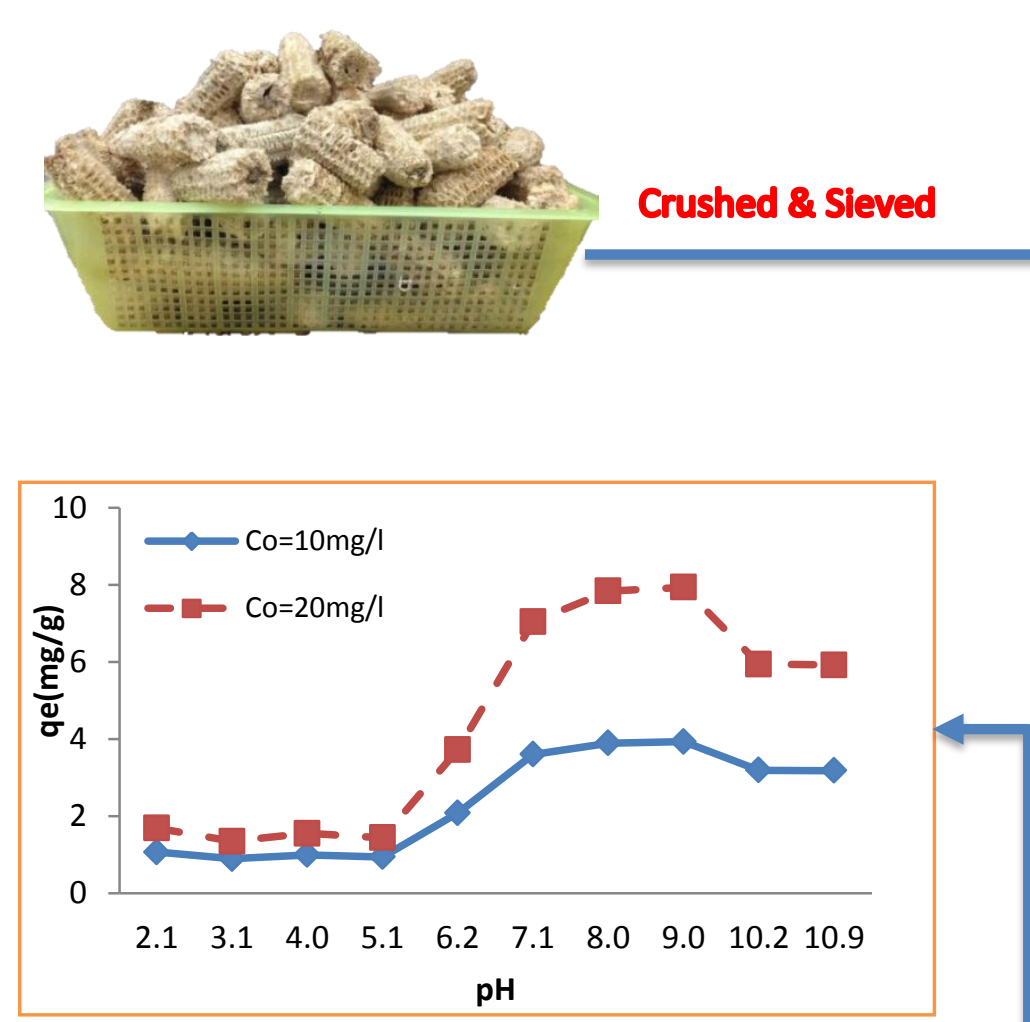

Ammonium removal by modified corncob biochar

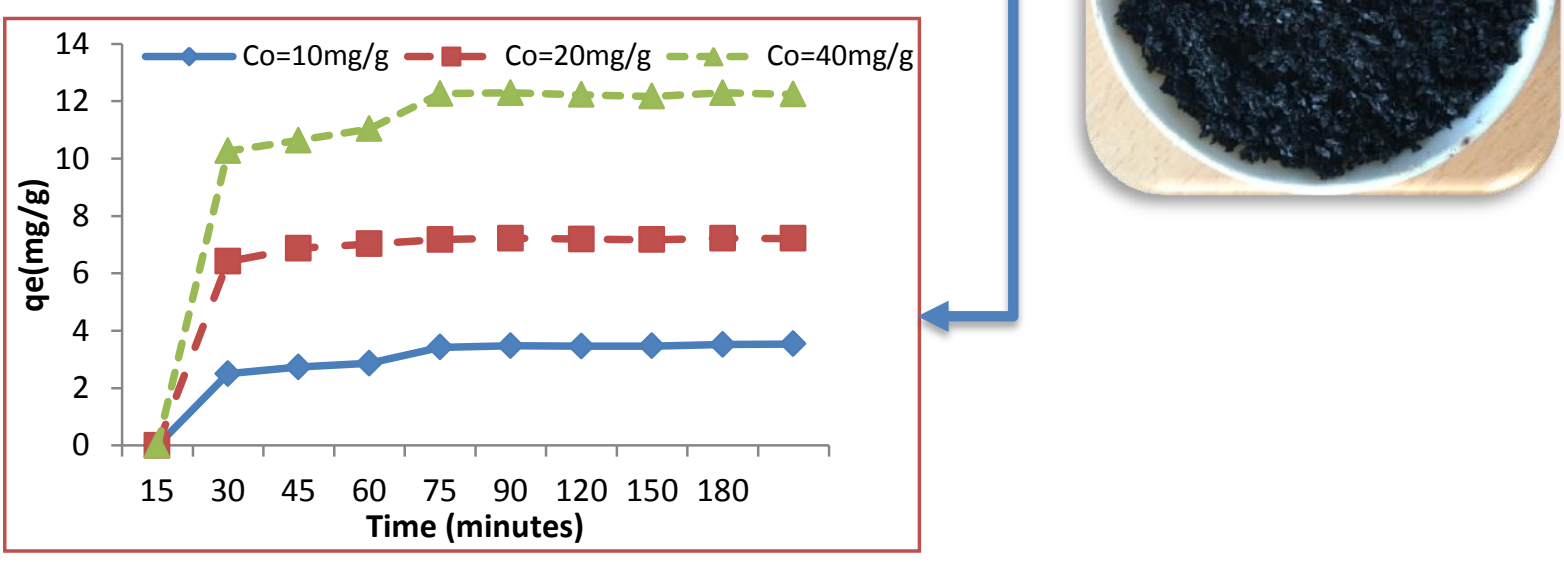

\section{ABSTRACT}

Ammonium pollution in groundwater and surface water is of major concern in many parts of the world due to the danger it poses to the environment and people's health. This study focuses on the development of a low cost adsorbent, specifically a modified biochar prepared from corncob. Evaluated here is the efficiency of this new material for removing ammonium from synthetic water (ammonium concentration from 10-100mg/L). The characteristics of the 
modified biochar were determined by Brunauer-Emmett-Teller (BET) test, Fourier transform infrared spectroscopy (FTIR) and Scanning electron microscopy (SEM). It was found that ammonium adsorption on modified biochar strongly depended on $\mathrm{pH}$. Adsorption kinetics of $\mathrm{NH}_{4}{ }^{+}-\mathrm{N}$ using modified biochar followed the pseudo-second order kinetic model. Both Langmuir and Sips adsorption isotherm models could simulate well the adsorption behavior of ammonium on modificated biochar. The highest adsorption capacity of $22.6 \mathrm{mg} \mathrm{NH}_{4}{ }^{+} \mathrm{N} / \mathrm{g}$ modified biochar was obtained when the biochar was modified by soaking it in $\mathrm{HNO}_{3} 6 \mathrm{M}$ and $\mathrm{NaOH} 0.3 \mathrm{M}$ for $8 \mathrm{~h}$ and $24 \mathrm{~h}$, respectively. The high adsorption capacity of the modified biochar suggested that it is a promising adsorbent for $\mathrm{NH}_{4}{ }^{+}-\mathrm{N}$ remediation from water.

Keywords: Adsorption, Ammonium, Biochar, Corncob

\section{INTRODUCTION}

Ammonium is one of the major pollutants affecting both groundwater and surface water. Although the natural level of ammonium in surface water and groundwater is low (below $3 \mathrm{mg} / \mathrm{L}$ ), the high ammonium concentrations are found in some areas. In Vietnam, high ammonium concentrations of $70 \mathrm{mg} / \mathrm{L}$ and more than $55 \mathrm{mg} / \mathrm{L}$ were found in groundwater in Nam Du and Phu Lam villages, Hanoi (Lindenbaum, 2012 and Vietnam Environment Agency, 2016). The high level of human activities such as intensive development of livestock farms or the severe usage of nitrogen fertilizers are the causes of the high levels of ammonium in these areas (Vietnam Environment Agency, 2016; WHO, 2016). High ammonium concentrations are also found in the surface water in Vietnam. Recent reports by the Hanoi Centre for Environmental and Natural Resources Monitoring and Analysis (2016) show that the ammonium concentration in Van Chuong lake in Hanoi was $15.5 \mathrm{mg} / \mathrm{L}, 31$ times higher than surface water quality standards of Vietnam. 
Current water treatment methods such as coagulation and filtration are not able to remove ammonium effectively, especially in decentralized water treatment systems. Adsorption is considered to be an economic and effective method for removing ammonium (Moradi, 2011; Yahaya et al., 2011). A number of adsorbents such as, biochar, activated carbon (AC), zeolite with and without modification have been trialed for removing ammonium via the water treatment process (Balci and Dinçel, 2002; Vassileva et al., 2008; Lin et al., 2009; Huang et al.,2010; Huo et al.,2012; Otal et al., 2013; Cui et al., 2016).

A previous study by Moreno-Castilla et al. (2000) confirmed that the surface chemistry plays a more important role than the BET surface area of adsorbents and the pore structure in adsorbing inorganic compounds from groundwater. The modification strategy is a popular method to change the surface chemistry and improve the adsorption efficiency of adsorbents. The oxidation process with $\mathrm{H}_{3} \mathrm{PO}_{4}, \mathrm{HNO}_{3}, \mathrm{H}_{2} \mathrm{O}_{2}$ or $\mathrm{KMnO}_{4}$ has been applied for modifying the AC's surface characteristics (Moreno-Castilla et al., 2000; Soto-Garrido et al., 2003; Vassileva et al., 2008; El-Wakil et al., 2014). Soto-Garrido et al., (2003) investigated the chemical modification of activated carbon made from peach stones in adsorbing ammonium. Their results indicated that modified activated carbon with $\mathrm{HNO}_{3} 6 \mathrm{M}$ was more efficient in ammonium adsorption than when applying $\mathrm{H}_{2} \mathrm{O}_{2} 6 \mathrm{M}$. More recently, El-Wakil et al. (2014) analyzed the removal of $\mathrm{Pb}^{2+}$ from groundwater by modified activated carbon generated from hyacinth. In their study, hyacinth was sequentially impregnated with $\mathrm{H}_{3} \mathrm{PO}_{4}$ and $\mathrm{HNO}_{3}$ solutions (impregnation ratios of 1:3 and 1:1 w/v, respectively). Halim et al. (2013) also found that the activated carbon modified by $\mathrm{HNO}_{3}(37 \%)$ and $\mathrm{NaOH} 1 \mathrm{M}$ had better ammonium adsorption capacity than the original activated carbon. Each gram of this material could adsorb $19.34 \mathrm{mg}$ ammonium, four time higher than the original one $(4.5 \mathrm{mg} / \mathrm{g})$ when treating groundwater of $685-735 \mathrm{mg} \mathrm{NH}_{4}{ }^{+} / \mathrm{L}$. 
Biomass recently has been used to produce $\mathrm{AC}$ for removing different pollutants from water due to its low cost and wide availability. Corncob waste is generally used as a food source for livestock and the excess can be burnt. In Vietnam, million tons of agricultural by-products like corn cob, rice straw, etc., are burnt every year in the field which causes air, soil and water pollution. The reuse of these low cost agricultural by-products as new adsorbents for wastewater treatment will contribute to the reduction of green-house emissions. To improve their value, corncob should be used to produce AC which can then be applied to removing pollutants such as ammonium from water. Because the adsorption capacity of AC prepared from corncob is still limited, this AC needs to be modified to improve its adsorption capacity. Thus, in this study corncob was firstly carbonized at $400^{\circ} \mathrm{C}$ to produce corncob biochar (BCC). The $\mathrm{BCC}$ was then modified by $\mathrm{HNO}_{3}$ and $\mathrm{NaOH}$ to produce a modified corncobbiochar which could very efficiently adsorb ammonium to a high degree. The objective of this paper is to: (i) determine the best conditions for preparing a modified corncob biochar; and (ii) evaluate the performance of this material in removing ammonium from water through the equilibrium and kinetics studies.

\section{MATERIALS AND METHODS}

\subsection{Materials}

A stock solution of $\mathrm{NH}_{4}{ }^{+}-\mathrm{N}$ with a concentration of $1.0 \mathrm{~g} / \mathrm{L}$ was obtained by dissolving accurately weighed $3.82 \mathrm{~g} \mathrm{NH}_{4} \mathrm{Cl}$ (analytical grade) in $1000 \mathrm{~mL}$ of deionized, distilled water in a volumetric flask. The corncob sample used in this study was collected from Da Bac district, Hoa Binh province, Vietnam. Its average moisture and ash contents were $15.71 \%$ and $8.81 \%$, respectively. 


\subsection{Optimization of biochar modification}

The corncob was firstly washed three times with tap water, three times with distilled water and dried in an oven at $100^{\circ} \mathrm{C}$ for 2 hours. The dried corncob was then crushed and sieved to a size of $0.5-2 \mathrm{~mm}$. The corncob biochar BCC was prepared by heating it under slow pyrolysis at $400^{\circ} \mathrm{C}$ for $1 \mathrm{~h}$ in a furnace (Nabertherm, model L3/11/B170, Germany). BCC was then modified by soaking it in a solution of $\mathrm{HNO}_{3}$ for 8 hours. Following that, the biochar was washed three times with distilled water. This is the first modified corncob biochar -the MBCC1. For optimizing the modified conditions for $\mathrm{MBCC} 1$, the $\mathrm{HNO}_{3}$ concentration and impregnation ratio (weight/volume) of $\mathrm{BCC} / \mathrm{HNO}_{3}$ were varied from $2 \mathrm{M}$ to $8 \mathrm{M}$ and $1: 1$ to 1:7, respectively. The $\mathrm{MBCC} 1$ was then soaked in $\mathrm{NaOH}$ solution for 24 hours, and then was washed several times with distilled water until a $\mathrm{pH}$ of 7-8 was reached. The dried product was referred to as the second modified corncob-biochar - MBCC2. Here the $\mathrm{NaOH}$ concentration was varied from $0.1 \mathrm{M}$ to $0.5 \mathrm{M}$ and the impregnation ratio (weight/volume) of $\mathrm{MBCC} 1 / \mathrm{NaOH}$ of 1:20 was used. The impregnation ratio of 1:20 was selected following the findings of Trinh (2009). The $\mathrm{HNO}_{3}, \mathrm{NaOH}$ concentrations and impregnation ratio of $\mathrm{BCC} / \mathrm{HNO}_{3}$ that led to the highest $\mathrm{NH}_{4}{ }^{+}-\mathrm{N}$ adsorption amount were chosen as the optimum scenario for preparing modified corncob biochar.

The experimental conditions for optimization are summarized in the following flowchart. 


\section{Optimization of $\mathrm{HNO}_{3}$ concentration}

- $\mathrm{HNO}_{3}$ concentration: $\mathrm{HNO}_{3} 2 \mathrm{M}, 4 \mathrm{M}, 6 \mathrm{M}, 8 \mathrm{M}$ Impregnation ratio of $\mathrm{BCC} / \mathrm{HNO}_{3}$ (weight/volume): 1:5

Optimization of impregnation ratio of $\mathrm{BCC} / \mathrm{HNO}_{3}$ (weight/volume)

- Optimum $\mathrm{HNO}_{3}$ concentration from the $1^{\text {st }}$ step

- Impregnation ratio of $\mathrm{BCC} / \mathrm{HNO}_{3}$ (weight/volume): 1:1, 1:3, $1: 5,1: 7$

\section{Optimization of $\mathrm{NaOH}$ concentration}

- Optimum $\mathrm{HNO}_{3}$ concentration from the $1^{\text {st }}$ step

- Optimum impregnation ratio of $\mathrm{BCC} / \mathrm{HNO}_{3}$ from the $2^{\text {nd }}$ step

- $\mathrm{NaOH}$ concentration: $0.1 \mathrm{M}, 0.3 \mathrm{M}, 0.5 \mathrm{M}$

\subsection{Characteristics of Modified Corncob Biochar}

The MBCC1 and MBCC2 samples produced at the optimizated conditions and BCC were used for characterization. The textural characteristics of samples were determined by $\mathrm{N}_{2}$ adsorption at $77 \mathrm{~K}$ with an accelerated surface area and porosimeter (ASAP-200, Micromeritics). Specific surface area was calculated from the isotherms using the BrunauerEmmett-Teller (BET) equation. SEM images were recorded using an electron microscope S4800 (FE-SEM, Hitachi).

The surface chemical group of $\mathrm{BCC}, \mathrm{MBCC} 1, \mathrm{MBCC} 2$ in terms of both quantity and quality was assessed by Boehm titration. Titration was conducted to determine the surface functional groups of the produced char. Solutions of $\mathrm{NaOH}(0.05 \mathrm{~mol} / \mathrm{L}), \mathrm{NaHCO}_{3}(0.05 \mathrm{~mol} / \mathrm{L})$ and $\mathrm{Na}_{2} \mathrm{CO}_{3}(0.05 \mathrm{~mol} / \mathrm{L})$, and $50 \mathrm{~mL}$ of each solution were added to $0.5 \mathrm{~g}$ of each product in bottles and placed in a shaker for 24 hours; after shaking, the sample was filtered. The $10 \mathrm{~mL}$ filtrate was titrated using standard $\mathrm{HCl} 0.05 \mathrm{~mol} / \mathrm{L}$ for basic solutions $\left(\mathrm{NaOH}, \mathrm{NaHCO}_{3}\right.$ and 
$\mathrm{Na}_{2} \mathrm{CO}_{3}$ ). For the titration of $\mathrm{NaOH}$ solutions, phenolphthalein was used as an indicator while for $\mathrm{Na}_{2} \mathrm{CO}_{3}$ and $\mathrm{NaHCO}_{3}$, methyl orange indicator was employed. The acidic groups were calculated on the basis that: $\mathrm{NaOH}$ neutralizes carboxylic, lactonic and other acidic groups; $\mathrm{Na}_{2} \mathrm{CO}_{3}$ neutralizes carboxylic and lactonic groups; and $\mathrm{NaHCO}_{3}$ neutralizes only the carboxylic group.

Surface functional groups on the sample were studied utilizing a Fourier Transform Infrared Spectrometer (FTIR, NEXUS 670, Nicolet, USA). The spectra were recorded from 4000 to $400 \mathrm{~cm}^{-1}$. By comparing them to the standard frequency patterns, various characteristic chemical bonds (or stretchings) were determined, from which certain surface functional groups could be derived.

\subsection{The study of ammonium adsorption by adsorbents}

Experiments were conducted using Jar test equipment (model: JLT6 Jar test/Flocclulator, Italy) with a rotational speed of $100 \mathrm{rev} / \mathrm{min}$. In the study, $0.5 \mathrm{~g}$ adsorbent $(\mathrm{BCC}, \mathrm{MBCC} 1$, and MBCC2) was placed into $250 \mathrm{~mL}$ ammonium solution.

The effect of $\mathrm{pH}$ on the adsorption of ammonium by modified biochar was studied by varying the $\mathrm{pH}$ of $\mathrm{NH}_{4} \mathrm{Cl}$ solution from 2 to 11 using diluted $\mathrm{HCl} 0.1 \mathrm{M}$ or $\mathrm{NaOH} 0.1 \mathrm{M}$

For the kinetics study, samples were collected after 5, 10, 15, 30, 60, 90, 120, 150 and 180 min mixing between adsorbent with ammonium solution of predetermined concentrations (10, 20, and $40 \mathrm{mg} / \mathrm{L}$ of ammonium). The adsorption equilibrium analysis was conducted with ammonium solutions of $10,20,40,60,80$, and $100 \mathrm{mg} / \mathrm{L}$. The samples were then collected after the mixing time of 120 min. For the ammonium analysis, samples were filtered and the ammonium concentration in the solution was determined via a colorimetric method (Rozic et al., 2000), using UV-VIS spectrophotometer (model: UV-752, USA) at $\lambda=640 \mathrm{~nm}$. Finally, the amount of ammonium in the adsorbent (qe $(\mathrm{mg} / \mathrm{g})$ ) was calculated by the mass transfer 
balance relationship, $q_{e}=\left(C_{o}-C_{e}\right) V / W$. Here $\mathrm{C}_{0}$ and $\mathrm{Ce}(\mathrm{mg} / \mathrm{L})$ represent the influent and equilibrium concentrations, respectively.

\section{RESULTS AND DISCUSSION}

\subsection{Optimization of biochar modification}

\subsubsection{Ammonium adsorption capacities of BCC, $M B C C 1$ and $M B C C 2$}

An initial test was carried out to compare the performance of original corncob biochar BCC with modified corncob biochar MBCC1 and MBCC2. Here, MBCC1 was prepared by soaking $\mathrm{BCC}$ with $\mathrm{HNO}_{3} 4 \mathrm{M}$ and the impregnation ratio $\mathrm{BCC} / \mathrm{HNO}_{3}$ of $1: 5 . \mathrm{MBCC} 2$ was prepared by modifying $\mathrm{MBCC} 1$ with $\mathrm{NaOH} 0.3 \mathrm{M}$ and impregnation ratio $\mathrm{MBCC} 1 / \mathrm{NaOH}$ of 1:20. The amount of ammonium adsorbed by corncob biochars (qe (mg/g)) with and without modification is presented in Table 1.

\section{Table 1}

Comparison of $\mathrm{NH}_{4}{ }^{+}$adsorption of $\mathrm{BCC}, \mathrm{MBCC} 1$ and $\mathrm{MBCC} 2$

\begin{tabular}{|c|c|c|c|}
\hline \multirow{2}{*}{$\mathrm{C}_{\mathrm{o}}(\mathrm{mg} / \mathrm{l})$} & \multicolumn{3}{|c|}{ Adsorption amount $q_{e}(\mathrm{mg} / \mathrm{g})$} \\
\hline & BCC & MBCC1 & MBCC2 \\
\hline 20 & 2.45 & 2.60 & 3.52 \\
\hline 40 & 2.95 & 4.00 & 5.58 \\
\hline 60 & 3.5 & 8.60 & 11.67 \\
\hline
\end{tabular}

The above results show that corncob biochar is able to adsorb ammonium. However, the amount adsorbed by BCC is small (less than $3.5 \mathrm{mg} / \mathrm{g}$ ) and its value could be improved when it was modified by $\mathrm{HNO}_{3}$ and $\mathrm{NaOH}$, especially for water with high concentration of $\mathrm{NH}_{4}{ }^{+}-\mathrm{N}$. The amount of $\mathrm{NH}_{4}{ }^{+}-\mathrm{N}$ adsorbed on modified biochar is found to be higher than that adsorbed by original biochar. This improvement can be explained by the increase in active functional 
groups. These include, for example, carboxylic, lactonic and acidic groups for adsorpting $\mathrm{NH}_{4}{ }^{+}-\mathrm{N}$. The detailed analysis is presented in the next section (section 3.2). The results also showed that the adsorption capacity of MBCC2 for $\mathrm{NH}_{4}{ }^{+}-\mathrm{N}$ was higher than that of MBCC1. This can be explained by the fact that when $\mathrm{MBCC} 1$ was soaked with $\mathrm{NaOH}$, acid functional groups on the surface of $\mathrm{MBCC} 1$ reacted with $\mathrm{NaOH}$ to form RCOONa. The RCOONa in MBCC2 helped to increase the segregation of modified biochar MBCC2 in water and thus increased the ammonium exchange capacity of MBCC2 (Halim et al., 2013).

Based on the above findings, the adsorption capacity of MBCC2 was found to be the better than the MBCC1. Therefore the following experiments focused on evaluating the performance of MBCC2.

\subsubsection{Effect of $\mathrm{HNO}_{3}$ concentration on modification}

The effect of $\mathrm{HNO}_{3}$ concentration on the performance of MBCC2 was evaluated at the impregnation ratio of $\mathrm{BCC} / \mathrm{HNO}_{3}$ solution of 1:5 (weight/volume). The primary experiment shows that $\mathrm{BCC}$ was damaged when it was soaked with $\mathrm{HNO}_{3}$ at a high temperature of over $80^{\circ} \mathrm{C}$. Therefore the modification with $\mathrm{HNO}_{3}$ was only conducted at room temperature $\left(25^{\circ} \mathrm{C}\right)$.

The amounts of ammonium adsorbed by MBCC2 produced from different $\mathrm{HNO}_{3}$ concentrations of $2 \mathrm{M}, 4 \mathrm{M}, 6 \mathrm{M}$, and $8 \mathrm{M}$ are presented in Table 2.

Table 2

Effect of $\mathrm{HNO}_{3}$ concentration on amount adsorbed by MBCC2

\begin{tabular}{ccccc}
\hline \multirow{2}{*}{$\mathbf{C}_{\mathbf{0}}(\mathbf{m g} / \mathbf{l})$} & & \multicolumn{4}{c}{ Adsorption amount qe $(\mathbf{m g} / \mathbf{g})$} \\
& MBCC2 $(\mathbf{2 M})$ & $\mathbf{M B C C 2}(\mathbf{4 M})$ & $\mathbf{M B C C 2}(\mathbf{6 M})$ & MBCC2 (8M) \\
\hline 20 & 2.28 & 3.52 & 7.67 & 7.07 \\
40 & 3.48 & 5.58 & 12.05 & 11.90 \\
60 & 8.70 & 11.67 & 13.64 & 11.94 \\
\hline
\end{tabular}


The experimental results indicate that adsorption capacity of modified corncob biochar could be improved by modifying it with $\mathrm{HNO}_{3}$ and the concentration of $\mathrm{HNO}_{3}$ had a strong effect on the modified product. The $\mathrm{HNO}_{3}$ concentrations of $2 \mathrm{M}$ and $4 \mathrm{M}$ were not enough to create the highly active surface functional groups. At $60 \mathrm{mg} \mathrm{NH}{ }_{4}^{+} / \mathrm{L}$, the highest $\mathrm{NH}_{4}{ }^{+}$amount adsorbed by $\mathrm{MBCC} 2$ only reached $11.67 \mathrm{mg} / \mathrm{L}$ when the modified corncob biochar was produced from the modification process with a $\mathrm{HNO}_{3}$ concentration of less than $4 \mathrm{M}$. The $\mathrm{NH}_{4}{ }^{+}$amount adsorbed by MBCC2 reached the highest value of $13.64 \mathrm{mg} / \mathrm{g}$ in the case of corncob activated carbon was impregnated with $\mathrm{HNO}_{3} 6 \mathrm{M}$. The lower adsorption capacities when the $2 \mathrm{M}$ and $4 \mathrm{M}$ solutions of $\mathrm{HNO}_{3}$ were utilized can be explained by the limited number of acidic groups created on the corncob activated carbon surface.

The further increase in $\mathrm{HNO}_{3}$ concentration from $6 \mathrm{M}$ to $8 \mathrm{M}$, in contrast, did not improve the adsorption capacity of MBCC2. This increase even led to a decline in adsorption capacity at all initial ammonium concentrations. This phenomenon can be explained as follows. When the $\mathrm{HNO}_{3}$ concentration was too high, the oxidation process was strong enough to break down part of the structure of corncob activated carbon and reduce its efficiency. Consequently, the $\mathrm{HNO}_{3}$ concentration of $6 \mathrm{M}$ was chosen in the subsequent experiments.

\subsubsection{Effect of impregnation ratio on modification}

The effect of impregnation ratio between corncob biochar and $\mathrm{HNO}_{3}$ on the adsorption capacity of modified corncob biochar is presented in Table 3. 
Table 3

Effect of impregnation ratio of corncob biochar and $\mathrm{HNO}_{3}$ on the $\mathrm{NH}_{4}{ }^{+}$amount adsorbed by MBCC2

\begin{tabular}{|c|c|c|c|c|}
\hline \multirow[b]{2}{*}{ Co (mg/l) } & \multicolumn{4}{|c|}{ Adsorption amount $q_{e}(\mathrm{mg} / \mathrm{g})$} \\
\hline & $\operatorname{MBCC2}(1: 1)$ & $\operatorname{MBCC2}(1: 3)$ & $\operatorname{MBCC2}(1: 5)$ & $\operatorname{MBCC2}(1: 7)$ \\
\hline 10 & 2.33 & 2.41 & 3.04 & 2.98 \\
\hline 20 & 4.92 & 5.01 & 7.67 & 6.00 \\
\hline 40 & 7.61 & 7.74 & 12.05 & 12.02 \\
\hline
\end{tabular}

When increasing the impregnation ratio from 1:1 to 1:5 (weight/volume), the adsorption capacity for ammonium was increased accordingly. However, this value was marginally decreased when this ratio rose to 1:7 in all the studied ammonium concentrations. Thus, the $\mathrm{HNO}_{3} 6 \mathrm{M}$ and impregnation ratio of 1:5 were chosen as the optimum acid modification state and used in the subsequent experiments.

\subsubsection{Effect of $\mathrm{NaOH}$ concentration on modification}

The experiments to assess the effect of $\mathrm{NaOH}$ concentration $(0.1 \mathrm{M}, 0.3 \mathrm{M}$ and $0.5 \mathrm{M})$ on preparing MBCC2 were conducted at $\mathrm{HNO}_{3}$ concentration of $6 \mathrm{M}$ and $\mathrm{BCC} / \mathrm{HNO}_{3}$ impregnation ratio of 1:5 (Table 4).

\section{Table 4}

Effect of $\mathrm{NaOH}$ concentration on the $\mathrm{NH}_{4}{ }^{+}$amount adsorbed by MBCC2

\begin{tabular}{|c|c|c|c|}
\hline \multirow[b]{2}{*}{ Co (mg/l) } & \multicolumn{3}{|c|}{ Adsorption amount $q_{\mathrm{e}}(\mathrm{mg} / \mathrm{g})$} \\
\hline & $\begin{array}{c}\text { MBCC2 } \\
(\mathrm{NaOH} \mathrm{0.1M)}\end{array}$ & $\begin{array}{c}\text { MBCC2 } \\
(\mathrm{NaOH} \mathrm{0.3M)}\end{array}$ & $\begin{array}{c}\text { MBCC2 } \\
(\mathrm{NaOH} \mathrm{0.5M})\end{array}$ \\
\hline 10 & 2.47 & 3.04 & 3.42 \\
\hline 20 & 4.93 & 7.67 & 7.45 \\
\hline 40 & 8.26 & 12.05 & 11.86 \\
\hline
\end{tabular}


The results show that when $\mathrm{NaOH}$ concentration was altered from $0.1 \mathrm{M}$ to $0.3 \mathrm{M}$, the capacity of MBCC2 to adsorb the ammonium increased. However, this adsorption capacity decreased slightly when the $\mathrm{NaOH}$ concentration exceeded $0.3 \mathrm{M}$. The reason for this is similar to what happened when $\mathrm{HNO}_{3}$ concentration rose from $6 \mathrm{M}$ to $8 \mathrm{M}$. Therefore, $\mathrm{NaOH}$ of $0.3 \mathrm{M}$ was chosen as the optimal concentration for modification of corncob biochar.

\subsection{Characteristics of biochar and modified biochar}

The SEM micrograghs of $\mathrm{BCC}$ and $\mathrm{MBCC} 2$ (Fig. 1) indicate that their structures were homogeneous. The structure of MBCC2 was not much different from that of BCC. The BET results reveal that the modification led to an increase in average pore volume, from $0.39 \mathrm{~m}^{3} / \mathrm{g}$ for the $\mathrm{BCC}$ to $0.61 \mathrm{~m}^{3} / \mathrm{g}$ for the $\mathrm{MBCC} 2$. However, the surface area was found to reduce significantly after modification, from $0.959 \mathrm{~m}^{2} / \mathrm{g}$ to $0.051 \mathrm{~m}^{2} / \mathrm{g}$ for the BCC and MBCC2, respectively. It was also observed that the pores of $\mathrm{BCC}$ were in microporous form whereas those of MBCC2 were not. The combination of micropores with the larger pores due to the chemical modification can explain the increase in pore volume and decrease in surface area.

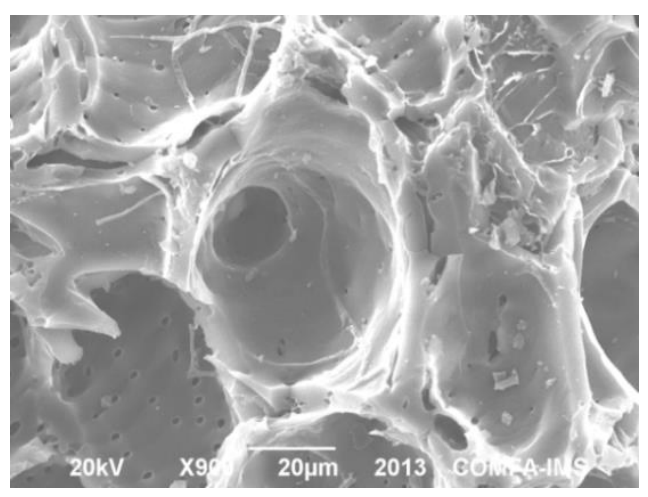

$\mathrm{BCC}$

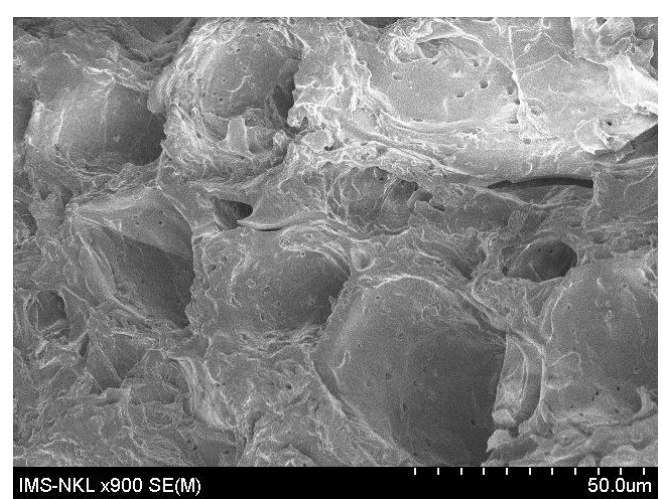

$\mathrm{MBCC} 2$

Fig. 1. SEM images of BCC and MBCC2

The chemical characteristics analyzed by Boehm titration of $\mathrm{BCC}, \mathrm{MBCC} 1$ and $\mathrm{MBCC} 2$ are presented in Table 5. 


\section{Table 5}

Chemical characteristics of corncon biochar, and modified corncob biochar

\begin{tabular}{lccc}
\hline Biochar & $\begin{array}{c}\text { Carboxylic } \\
(\mathbf{m m o l} / \mathbf{g})\end{array}$ & Lactonic $(\mathbf{m m o l} / \mathbf{g})$ & Acidic $(\mathbf{m m o l} / \mathbf{g})$ \\
\hline BCC & 0.6194 & 1.479 & 2.584 \\
MBCC1 & 1.3682 & 2.745 & 4.298 \\
MBCC2 & 0.8715 & 1.864 & 3.466 \\
\hline
\end{tabular}

The data in Table 5 illustrate that the amount of carboxylic and lactonic functional groups in MBCC1 were approximately double that of BCC. The other acidic functional group in the MBCC1 was also increased significantly. These results indicate that more active functional groups for adsorpting $\mathrm{NH}_{4}{ }^{+}-\mathrm{N}$ was presented in the modified material which consequently led to an improvement in the $\mathrm{NH}_{4}{ }^{+}-\mathrm{N}$ adsorption capacity of the modified biochar. The MBCC2 contains more carboxylic, lactonic and acidic groups than the original corncob biochar. However, there were less of these functional groups in MBCC2 compared to the MBCC1. The transfer from acidic forms into salt forms on the surface of modified corncob biochar when $\mathrm{MBCC} 1$ was soaked into $\mathrm{NaOH}$ could explain this phenomenon.

The FTIR results of $\mathrm{BCC}, \mathrm{MBCC} 1$ and $\mathrm{MBCC} 2$ are presented in Fig. 2. It shows that the spectrum of BCC did clearly change after modification. Here the adsorption spectrum wavelength was varied from 400 to $4000 \mathrm{~cm}^{-1}$. 


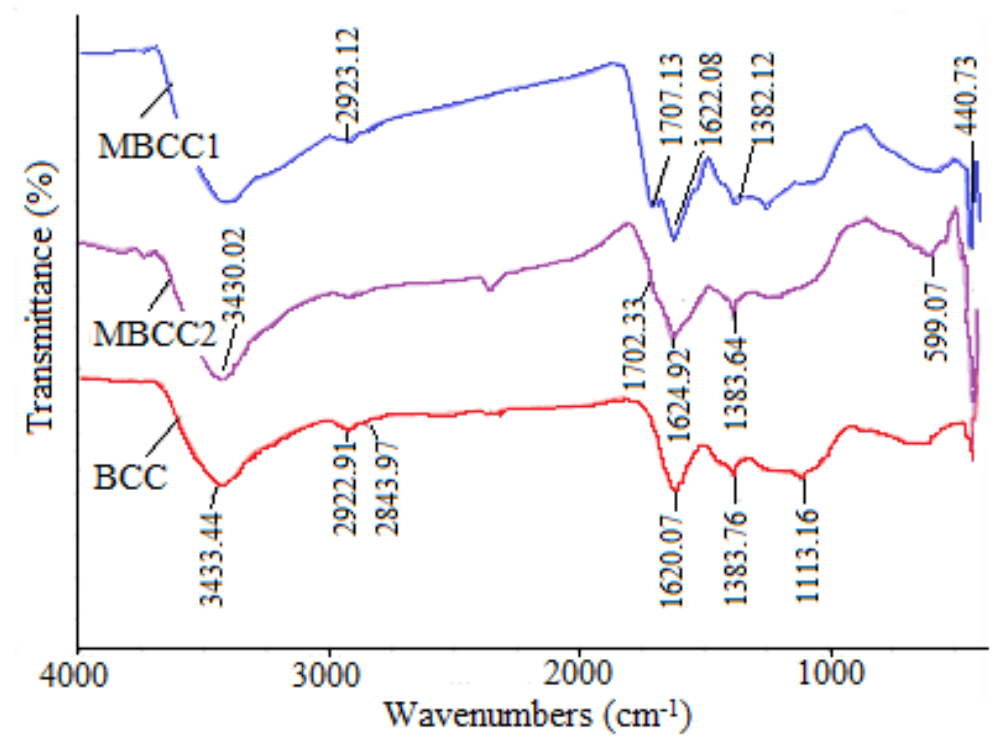

Fig. 2. The FTIR spectum of BCC, MBCC1 and MBCC2

Fig. 2 shows that the adsorption groups of $\mathrm{O}-\mathrm{H}$ (at peak at wavelength of $3433 \mathrm{~cm}^{-1}$ ) and $\mathrm{C}=\mathrm{C}$ (at peak at wavelength of $1620 \mathrm{~cm}^{-1}$ ) appeared in $\mathrm{BCC}$. The $\mathrm{O}-\mathrm{H}$ and $\mathrm{C}=\mathrm{C}$ groups also appeared in the MBCC1 and MBCC2 (at peak at wavelength of $3430 \mathrm{~cm}^{-1}$ and $1622-1624$ $\mathrm{cm}^{-1}$, respectively). However, the absorption intensity of the $\mathrm{O}=\mathrm{H}$ group of $\mathrm{MBCC} 1$ and MBCC2 was higher than that of BCC. Furthermore the modification led to the appearance of $\mathrm{C}=\mathrm{O}$ group (at 1702-1707 $\mathrm{cm}^{-1}$ ) in the MBCC1 and MBCC2. This indicates that the functional group of carboxylic acid did develop in both MBCC1 and MBCC2. Also the adsorption intensities of $\mathrm{O}-\mathrm{H}$ and $\mathrm{C}=\mathrm{O}$ groups of $\mathrm{MBCC} 2$ were lower than that of $\mathrm{MBCC} 1$ (Fig. 2). The reaction between the $\mathrm{O}-\mathrm{H}$ group in the carboxylic acid with $\mathrm{NaOH}$ during the second modification step could be the reason for this decrease. 


\subsection{Ammonium removal by $\mathrm{MBCC2}$}

\subsubsection{Effect of pH}

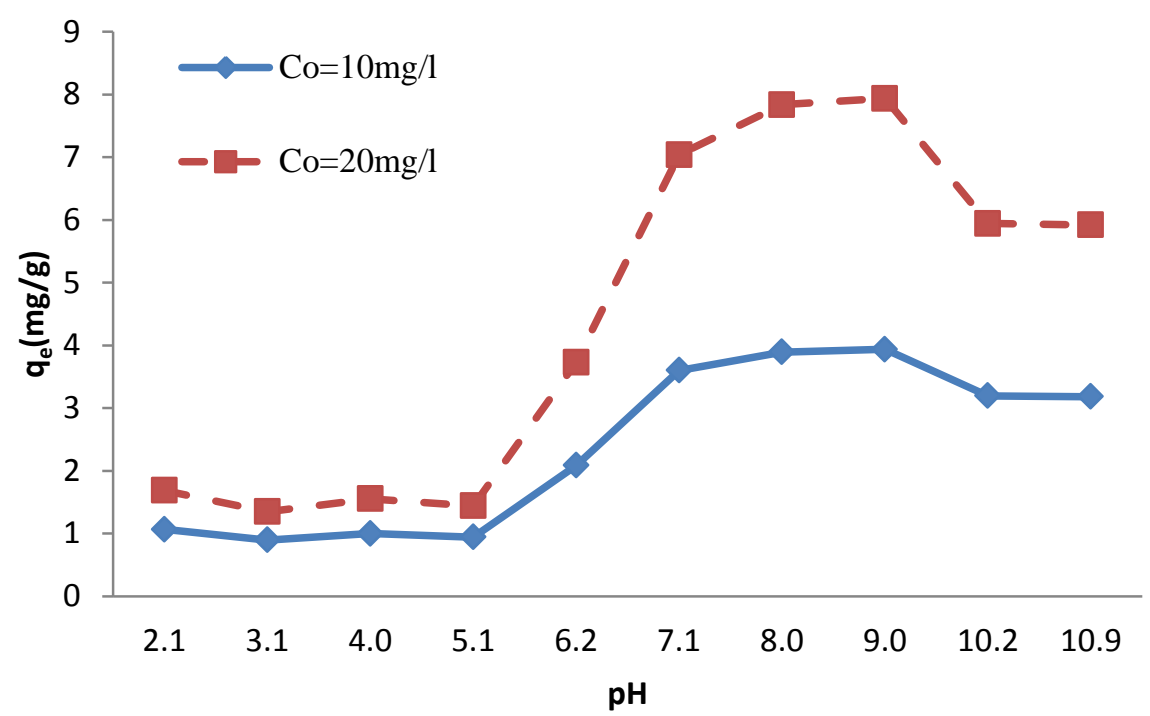

Fig. 3. Effect of $\mathrm{pH}$ on ammonium removal of $\mathrm{MBCC} 2$

Experimental results show that the amount of ammonium adsorbed by MBCC2 (Qe) was low when the $\mathrm{pH}$ ranged from 2 to 5 . However, it increased significantly when $\mathrm{pH}$ was increased from 5 to 8 and reached its highest value between 8 and $9 \mathrm{mg} / \mathrm{L}$ (Fig. 3). In fact, at $\mathrm{pH}$ between 8 and 9, ammonium adsorption reached $3.9 \mathrm{mg} / \mathrm{g}$ and $7.9 \mathrm{mg} / \mathrm{g}$ at intial ammonium concentration of 10 and $20 \mathrm{mg} / \mathrm{L}$, respectively. The continued increase of $\mathrm{pH}$ to more than 10 led to a margical decline in the adsorption amount of ammonium in the MBCC2.

The above results can be explained by the effects of $\mathrm{pH}$ on the existing state of $\mathrm{NH}_{4}{ }^{+}$ions in water and the ion state of surface functional groups of MBCC2. In solution, depending on the level of $\mathrm{pH}$, ammonium is mostly present as $\mathrm{NH}_{4}{ }^{+}$or $\mathrm{NH}_{3(\mathrm{aq})}$ forms. In the acidic environment, most ammonium exists in $\mathrm{NH}_{4}{ }^{+}$form in water (Marañón et al., 2006). The adsorption capacity was low at $\mathrm{pH}$ less than 5 because of the strong competition between $\mathrm{H}^{+}$and $\mathrm{NH}_{4}{ }^{+}$ions in the solution. The decrease of ion $\mathrm{H}^{+}$in the solution when increasing the $\mathrm{pH}$ of solution from 5 to 7 could help increase the adsorption capacity of MBCC2. Here, the adsorption of ammonium in water followed the ion exchange mechanism. Similar results have been documented by 
other researchers (Halim et al., 2013; Zeng et al., 2013). The adsorption capacity of MBCC2 for ammonium increased when the $\mathrm{pH}$ was increasd to more than 7 . The reason for this phenomenon was the electrostatic attraction mechanism in which $\mathrm{NH}_{4}{ }^{+}$interacted with the negatively charged surface of MBCC2.

Experimental study on the effect of $\mathrm{pH}$ on the ammonium removal was carried out with ten $\mathrm{pH}$ values from 2.1 to 10.9 . The $\mathrm{pKa}$ of ammonium is 9.3 so there was no ammonium stripping in most $\mathrm{pH}$ conditions studied (8 out of 10 conditions used). Experimental results show that the adsorption capacity of material decreased with the increasing of $\mathrm{pH}$ from 9 to 10.2 and 10.9. It indicated that at these high $\mathrm{pH}$ experimental conditions, ammonium stripping was not a main mechanism. In these conditions, most of the ammonium could be transformed into the $\mathrm{NH}_{3}(\mathrm{aq})$ form. Here the electrostatic attraction mechanism was no longer effective. This led to a reduction in the amount of ammonium removed. This finding is similar to the findings of Guo et al., (2005) and Vassileva et al., (2008). In the experiments, 250mL of samples were added into $250 \mathrm{~mL}$ conical flasks which were then covered by flasks' lids. The air volume in each flask was small (less than $10 \mathrm{~mL}$ ). Therefore, the ammonium removal by air stripping and evaporation during the experiments was minimized and could be ignored.

\subsubsection{Effect of contact time on adsorption capacity of ammonium}

The effect of contact time on ammonium adsorption is shown in Fig. 4. Adsorption capacity of ammonium increased significantly for the first $30 \mathrm{~min}$ and reached its maximum after 60 min. The $\mathrm{NH}_{4}{ }^{+}$amount adsorbed by MBCC2 was $3.47 \mathrm{mg} / \mathrm{g} ; 7.24 \mathrm{mg} / \mathrm{g}$ and $12.31 \mathrm{mg} / \mathrm{g}$ after $60 \mathrm{~min}$ for an intial ammonium concentration of 10, 20 and $40 \mathrm{mg} / \mathrm{L}$, respectively. After 60 min, adsorption capacity of ammonium did not increase when contact time was further increased. This indicated that the adsorption of ammonium by MBCC2 reached the point of saturation after 60 minutes of contact time. 


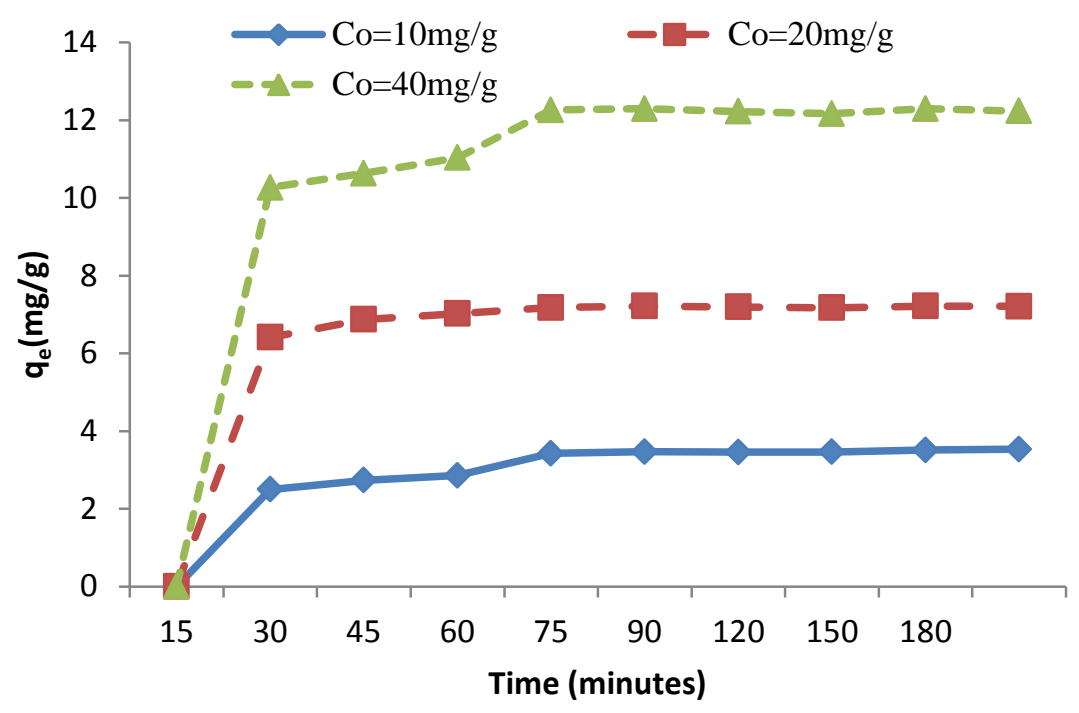

Fig. 4. Effect of contact time on ammonium adsorption by MBCC2

\subsection{Adsorption isotherm}

Adsorption isothermal equilibrium of MBCC2 for ammonium can be described using the Langmuir, Freundlich and Sips isotherms (Fig. 5). The Langmuir isotherm (Langmuir, 1918) is given by:

$$
q_{e}=\frac{q_{m} b C_{e}}{1+b C_{e}}
$$

Where: $\mathrm{q}_{\mathrm{m}}$ : saturated maximum monolayer adsorption capacity $(\mathrm{mg} / \mathrm{g})$; Ce: equilibrium concentration $(\mathrm{mg} / \mathrm{L})$, and $\mathrm{b}$ : Langmuir constant related to the binding energy of adsorption (L/mg).

The Freundlich isotherm (Freundlich, 1906) is an empirical equation. The equation of this model is written in equation 2:

$$
q_{e}=K_{F} C^{1 / n}
$$

Where: $\mathrm{K}_{\mathrm{F}}$ and $\mathrm{n}$ are Freundlich constant and an experimental constant, respectively. They indicate the adsorption capacity and adsorption intensity of the adsorbent. 
The Sips model is the combination of both the Langmuir and Freundlich isotherm models.

The Sips isotherm model can be written as follows:

$$
q_{e}=\frac{q_{m}\left(b C_{e}\right)^{1 / n}}{1+\left(b C_{e}\right)^{1 / n}}
$$

From the experimental data, the parameters of the Langmuir, Freundlich, and Sips were determined and the values are presented in Table 6.

\section{Table 6}

Paramaters of Langmuir, Freundlich, and Sips for ammonium adsorption of MBCC2

\begin{tabular}{cccc|ccc|cccc}
\hline & \multicolumn{3}{c|}{ Freundlich model } & \multicolumn{4}{c|}{ Langmuir model } & \multicolumn{4}{c}{ Sips model } \\
\cline { 2 - 11 } & $\mathrm{R}^{2}$ & $\mathrm{~K}_{\mathrm{F}}$ & $1 / \mathrm{n}$ & $\mathrm{R}^{2}$ & $\mathrm{q}_{\mathrm{m}}$ & $\mathrm{b}$ & $\mathrm{R}^{2}$ & $1 / \mathrm{n}$ & $\mathrm{q}_{\mathrm{m}}$ & $\mathrm{b}$ \\
\hline MBCC2 & 0.921 & 3.195 & 0.427 & 0.981 & 22.63 & 0.062 & 0.999 & 0.852 & 18.92 & 0.029 \\
\hline
\end{tabular}

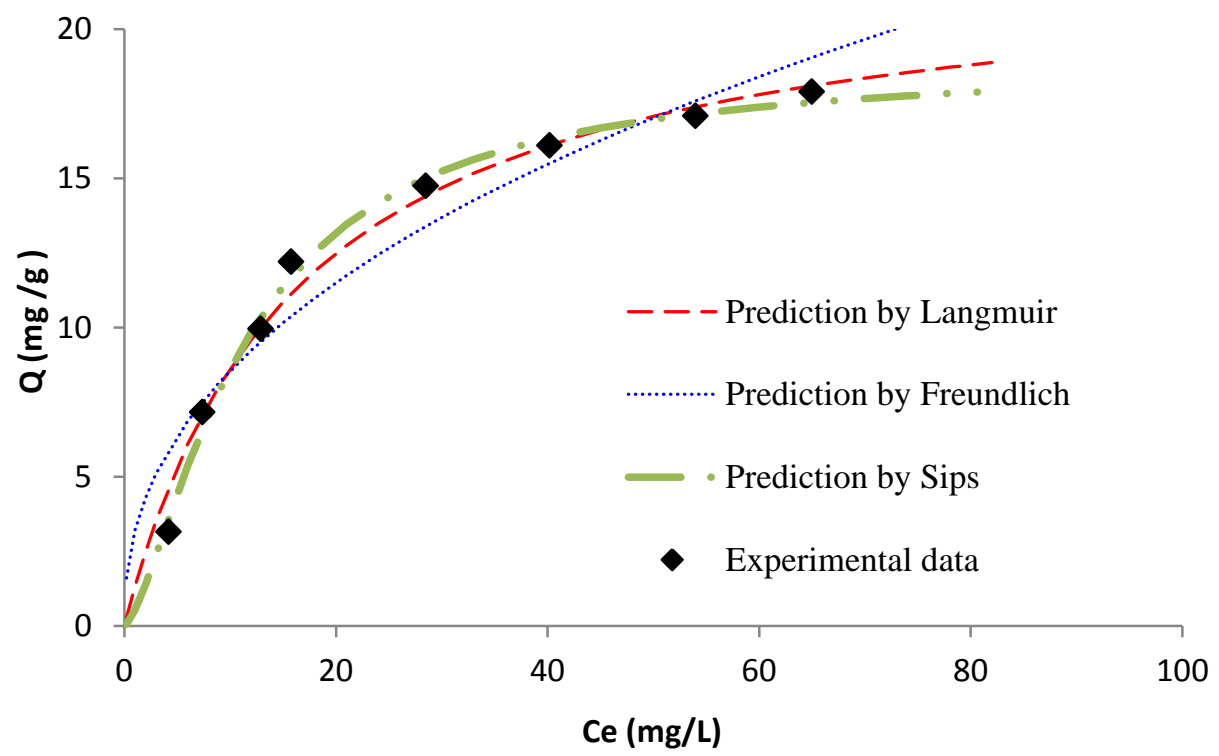

Fig. 5. Equilibrium adsorption prediction of ammonium on MBCC2 by Langmuir, Freundlich, and Sips models (contact time $=120 \mathrm{~min}, \mathrm{Co}=20 \mathrm{mg} / \mathrm{L}$ ) 
The regression efficient $\left(\mathrm{R}^{2}\right)$ obtained from the Langmuir and Sips models were closer to 1 and was much higher than that of the Freundlich model. In other words, Langmuir and Sips isotherms fitted well the $\mathrm{NH}_{4}{ }^{+}$adsorption on MBCC2. Thus, it can be concluded that the monolayer Langmuir adsorption isotherm explained better the adsorption of $\mathrm{NH}_{4}{ }^{+}$on MBCC2.

The favorable nature of adsorption can be expressed as $\mathrm{R}_{\mathrm{L}}$ and calculated by the following equation (Hall et al., 1966):

$$
R_{L=} \frac{1}{1+b C_{0}}
$$

Where $b$ is the Langmuir constant, Co is the initial ammonium concentration and $\mathrm{R}_{\mathrm{L}}$ is the dimensionless separation factor. The value of $\mathrm{R}_{\mathrm{L}}$ for $\mathrm{MBCC} 2$ was calculated as 0.06 and this indicates that the adsorption was a favorable process.

The maximum adsorption capacity, calculated from Langmuir isotherm, of BCC for ammonium was only $3.93 \mathrm{mg} / \mathrm{g}$ while that of MBCC2 was nearly 6 times higher, reaching $22.6 \mathrm{mg} / \mathrm{g}$. This proved that modification of $\mathrm{BCC}$ with $\mathrm{HNO}_{3}$ and $\mathrm{NaOH}$ helped to increase significantly the maximum adsorption capacity.

The MBCC2, although having a low specific surface, was able to adsorb large amounts of ammonium. Adsorption capacity for ammonium of by MBCC2 was also higher than that of several modified activated carbons (see Table 7). This shows that the specific surface of biochar is not a major factor for ammonium adsorption from water. This conclusion agrees with several previous studies (EL-Wakil et al., 2014; Takashi et al., 2006). According to Takashi et al., (2006), bamboo activated carbon carbonized at $400^{\circ} \mathrm{C}$ only had a specific surface of $2.17 \mathrm{~m}^{2} / \mathrm{g}$, however, its adsorption capacity of ammonium was higher than that of activated carbon with a specific surface of $1,670 \mathrm{~m}^{2} / \mathrm{g}$. 


\section{Table 7}

Comparison of ammonium adsorption capacity of different adsorbents

\begin{tabular}{|c|c|c|c|}
\hline Adsorbents & $\begin{array}{l}\quad \mathrm{NH}_{4}^{+} \\
\text {concentration } \\
\text { range }(\mathrm{mg} / \mathrm{L})\end{array}$ & $\begin{array}{c}\text { Maximum } \\
\text { adsorption } \\
\text { capacity } \\
\left(\mathrm{mg} \mathrm{NH}_{4}^{+} / \mathrm{g}\right)\end{array}$ & References \\
\hline $\begin{array}{l}\text { Slag } \\
\text { Honeycomb cinder } \\
\text { Coal gangue }\end{array}$ & $10-300$ & $\begin{array}{c}3.1 \\
5.0 \\
6\end{array}$ & $\begin{array}{l}\text { Zhang et al., } \\
\text { (2013) }\end{array}$ \\
\hline $\begin{array}{l}\text { Biochar } 400 \text { modification with } \\
\mathrm{H}_{2} \mathrm{SO}_{4} \\
\text { Biochar } 700 \text { modification with } \\
\mathrm{H}_{2} \mathrm{SO}_{4} \\
\text { Activated carbon modification with } \\
\mathrm{H}_{2} \mathrm{SO}_{4}\end{array}$ & $1-50$ & 10 & $\begin{array}{l}\text { Takashi et al., } \\
\text { (2006) }\end{array}$ \\
\hline $\begin{array}{l}\text { Activated carbon modification with } \\
\mathrm{Fe} \\
\text { Activated carbon modification with } \\
\mathrm{Cr}\end{array}$ & 100 & 14.5 & $\begin{array}{l}\text { Le Leuch and } \\
\text { Bandoz (2007) }\end{array}$ \\
\hline $\begin{array}{l}\text { Modified activated carbon with } \\
\mathrm{HNO}_{3}, \mathrm{NaOH}\end{array}$ & $685-735$ & 19.34 & $\begin{array}{l}\text { Halim et al., } \\
\text { (2013) }\end{array}$ \\
\hline $\begin{array}{l}\text { Modified activated carbon with } \\
\mathrm{HNO}_{3} \\
\text { Peach stones-granular activated } \\
\text { carbons }\end{array}$ & $\begin{array}{l}500 \\
500\end{array}$ & $\begin{array}{l}18 \\
10\end{array}$ & $\begin{array}{l}\text { Soto-Garrido } \\
\text { et al., (2003) }\end{array}$ \\
\hline $\begin{array}{l}\mathrm{BCC} \\
\mathrm{MBCC} 2\end{array}$ & $\begin{array}{l}100 \\
100\end{array}$ & $\begin{array}{l}3.93 \\
22.6\end{array}$ & This research \\
\hline
\end{tabular}

\subsection{Adsorption kinetics of $\mathrm{MBCC} 2$}

The dynamic behavior of adsorption of ammonium onto MBCC2 is determined from the kinetics experimental data. In this study, the experimental data were fitted with different adsorption kinetics models including pseudo-first order (Tseng et al., 2009), pseudo-second order (Kumar and Sivanesan, 2006), Elovich (Li et al., 2009) and Avrami (Lopes et al., 2003). Equations of these models are presented as follows:

$$
\begin{aligned}
& \text { Pseudo-first order }: q_{t}=q_{e}-q_{e} e^{-k_{1} t} \\
& \text { Pseudo-second order }: q_{t}=\frac{k_{2} q_{e}^{2} t}{1+k_{2} q_{e} t}
\end{aligned}
$$


Elovich

$$
: q t=\beta \cdot \ln (\alpha \beta t)
$$

Avrami

$$
: q_{t}=q_{e}\left\{1-\exp \left[k_{A V . t}\right] \operatorname{nav}\right\}
$$

Where, $\mathrm{q}_{\mathrm{e}}$ : adsorption capacity in balance; $\mathrm{K}_{1}, \mathrm{~K}_{2}$, and $\mathrm{K}_{\mathrm{av}}$ are constant rates of pseudo-first order, pseudo-second order, and Avrami models, respectively; $\alpha$ is the initial adsorption rate (mg/g.min); $\beta$ is the adsorption constant $(\mathrm{g} / \mathrm{mg})$ in the Elovich model; and $\mathrm{N}_{\mathrm{AV} 1}$ is the Avrami exponent of time in the Avrami model.

In the kinetics studies, the average relative error (ARE) was also calculated (equation 9):

$$
A R E=\frac{100}{N} \sum_{i=1}^{N}\left|\frac{q_{t e}-q_{m}}{q_{t e}}\right|_{i}
$$

Where $\mathrm{q}_{\mathrm{te}}(\mathrm{mg} / \mathrm{g})$ : amount of ammonium adsorbed on $\mathrm{MBCC} 2$, determined from the experimental study, $\mathrm{q}_{\mathrm{tm}}(\mathrm{mg} / \mathrm{g})$ : amount of ammonium adsorbed on $\mathrm{MBCC} 2$ predicted from the kinetics model, $\mathrm{N}$ : number of measurements. In contrast to $\mathrm{R}^{2}$ value, the kinetics model is better fitted if their ARE is lower. The kinetics parameters were calculated by non-linear regression using excel spreadsheet and optimized with the 'solver' add-in. Apart from $\mathrm{R}^{2}$, average relative error (ARE) was calculated for validation of kinetics models to experimental data to have a understanding of the adsorption process.

The model prediction data and experimental data are shown in Fig. 6. The models' parameters are summarized in Table 8. The simulation shows that the pseudo-second order model possessed the best fit with experimental data with the highest $R^{2}(0.965)$ and the lowest ARE (1.432). Furthermore, the calculated $\mathrm{q}_{\mathrm{e}}$ value by the pseudo-second order model was close to the experimental value. This finding demonstrates that: firstly, the ammonium sorption onto MBCC2 follows the pseudo-second order; and secondly, the rate of sorption was controlled by the chemical sorption process (Zhu et al., 2012). 


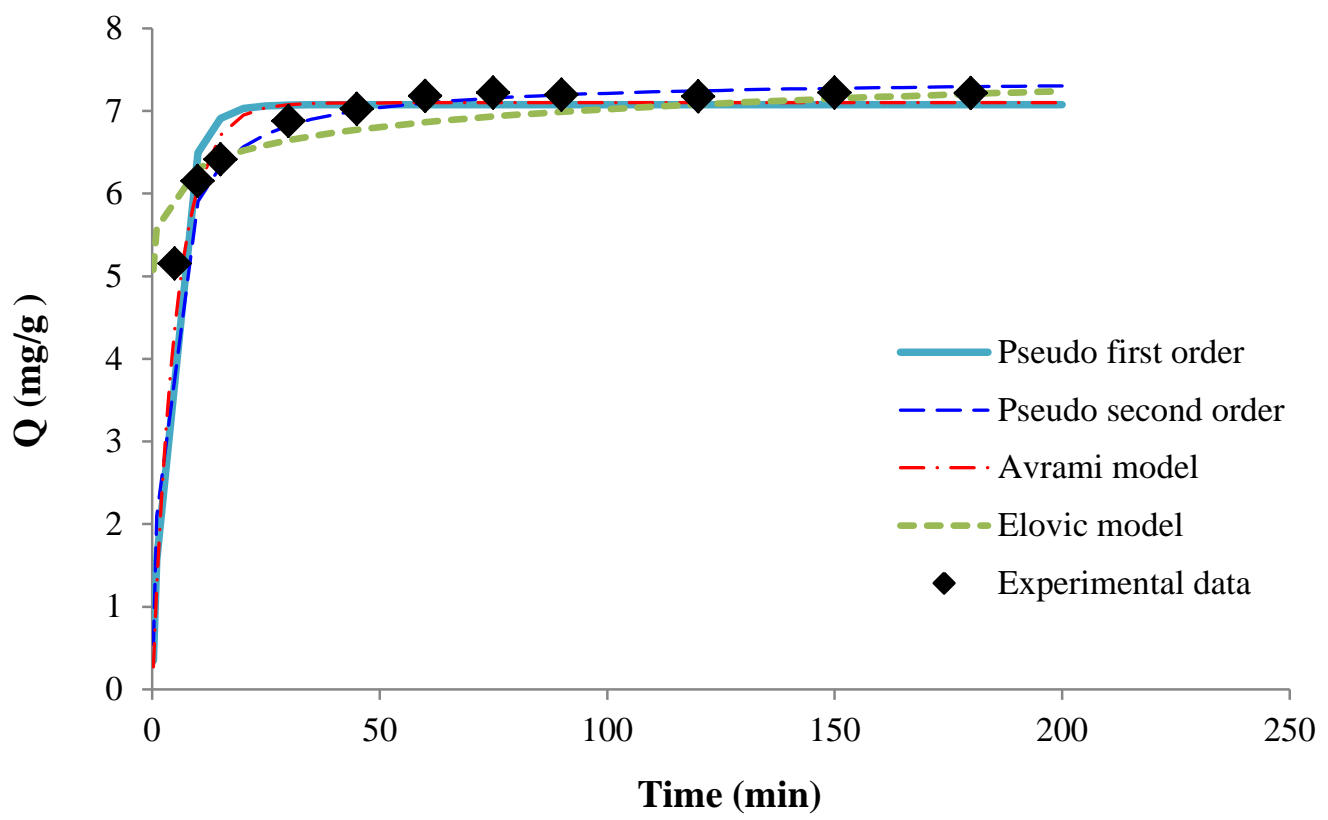

Fig. 6. Kinetics modelling of ammonium sorption onto MBCC2 (Co: $20 \mathrm{mg} / \mathrm{L}$; adsorbent amount: $2 \mathrm{~g} / \mathrm{L}$; initial $\mathrm{pH}: 7$ )

\section{Table 8}

Kinetics modelling parameters of ammonium sorption on MBCC2

\begin{tabular}{lll|lll}
\hline Model & Parameter & Value & Model & Parameter & Value \\
\hline Pseudo-first & $\mathrm{q}_{\mathrm{e}}$ & 7.077 & Pseudo-second & $\mathrm{q}_{\mathrm{e}}$ & 7.397 \\
order & $\mathrm{K}_{1}$ & 0.25 & order & $\mathrm{K}_{2}$ & 0.054 \\
& $\mathrm{R}^{2}$ & 0.882 & & $\mathrm{R}^{2}$ & 0.965 \\
\multirow{4}{*}{ Avrami } & $\mathrm{ARE}$ & 2.661 & & $\mathrm{ARE}$ & 1.432 \\
& $\mathrm{q}_{\mathrm{e}}$ & 7.10 & Elovich & $\alpha$ & $1.8 \times 10^{8}$ \\
& $\mathrm{~K}_{\mathrm{av}}$ & 0.693 & & $\beta$ & 0.313 \\
& $\mathrm{~N}_{\mathrm{av}}$ & 0.28 & & $\mathrm{R}^{2}$ & 0.710 \\
& $\mathrm{R}^{2}$ & 0.824 & & ARE & 3.766 \\
& $\mathrm{ARE}$ & 2.978 & & & \\
\end{tabular}

\section{CONLUSIONS}

This study shows that modification of surface of carbonized biochar made from corncob could significantly enhance ammonium adsorption efficiency. Here the biochar was modified 
effectively by treating it with $\mathrm{HNO}_{3}$ and $\mathrm{NaOH}$. The acid concentration of $6 \mathrm{M}$, impregnation ratios (weight/volume) of $\mathrm{BCC} / \mathrm{HNO}_{3} 1: 5(w / v)$ and then soaking in $\mathrm{NaOH} 0.3 \mathrm{M}$ constituted the best conditions for treating ammonium. The equilibrium data fitted well to the Langmuir and Sips models, and maximun adsorption capacity as determined by the Langmuir model was $22.6 \mathrm{mg} / \mathrm{g}$. The optimum $\mathrm{pH}$ for adsorping ammonium by MBCC2 was between 8 and 9 . The reaction reached equilibrium within 60 min and the kinetics of adsorption followed the pseudo-second order model. This study shows that MBCC2 has the potential to work as an adsorbent with very high adsorptive capacity for the removal of ammonium from water (groundwater and surface water). Its application can be extended to wastewater treatment. The exhausted adsorbents containing high ammonium could directly be used as soil conditioners. This approach reduces the need to regenerate the adsorbent and the maintenance requirements for the treatment system. Further studies on desorption, adsorption interference (such as calcium, magnesium, iron, organic) with the MBCC2 are planned to be carried out before considering the application of this material in water and wastewater treatment systems.

\section{REFERENCES}

Balci, S., Dinçel, Y., 2002. Ammonium ion adsorption with sepiolite: use of transient uptake method. Chemical engineering and processing: process intensification 41 (1), 79-85.

Cui, X., Hao, H., Zhang, C., He, Z., Yang, X., 2016. Capacity and mechanisms of ammonium and cadmium sorption on different wetland-plant derived biochars. Science of the Total Environment, 539, $566-575$

El-Wakil, A.M., El-Maaty, W.M.A., Wad, F.S., 2014. Removal of lead from aqueous solution on activated carbon and modified activated carbon prepared from dried water hyacinth plant. Journal of Analytical \& Bioanalytical Techniques 5 (187), 1-14.

Freundlich, H.M.F., 1906. Over the adsorption in solution. Journal of Physical Chemistry 57A, 370-485.

Guo, J., Xu, W.S., Chen, Y.L., Lua, A.C., 2005. Adsorption of $\mathrm{NH}_{3}$ onto activated carbon prepared from palm shells impregnated with $\mathrm{H}_{2} \mathrm{SO}_{4}$. Journal of Colloid and Interface Science 281 (2), 285-290.

Halim, A.A., Latif, M.T., Ithnin, A., 2013. Ammonia removal from aqueous solution using organic acid modified activated carbon. World Applied Sciences Journal 24 (1), 01-06.

Hall, K.R., Eagleton, L.C., Acrivos, A., 1966. Pore and solid-diffusion kinetics in fixed-bed adsorption under constant-pattern conditions. Industrial and Engineering Chemistry Fundamentals 5, 212-223. 
Hanoi Centre for Environmental and Natural Resources Monitoring and Analysis, 2016. Report on the water quality of lakes in Hanoi, Hanoi.

Huang, H., Xiao, X., Yan, B., Yang, L., 2010. Ammonium removal from aqueous solutions by using natural Chinese (Chende) zeolite as adsorbent. Journal of Hazardous Materials 175 (1-3), 247-252.

Huo, H., Lin, H., Dong, Y., Cheng, H., Wang, H., Cao, L., 2012. Ammonia-nitrogen and phosphates sorption from simulated reclaimed waters by modified clinoptilolite. Journal of Hazardous Materials 229, 292-297.

Kumar, K.V., Sivanesan, S. 2006. Selection of optimum sorption kinetics: comparison of linear and non-linear method. Journal of Hazardous Materials 134 (1-3), 277-279.

Langmuir, I. 1918. The sorption of gases on plane surface of glass, mica, and platinum. Journal of the American Chemical Society 40 (9), 1361-1403.

Le-leuch I.M., Bandoz, T.J., 2007. The role of water and surface acidity on the reactive adsorption of ammonia on modified activated carbons. Carbon 45 (3), 568-578.

Li, K., Zheng, Z., Huang, X., Zhao, G., Feng, J., Zhang, J., 2009. Equilibrium, kinetic, thermodynamic studies on the adsorption of 2-nitroaniline onto activated carbon prepared from cotton stalk fibre. Journal of Hazardous Materials 166 (1), 213-220.

Lindenbaum J, 2012. Identification of sources of ammonium in groundwater using stable nitrogen and boron isotopes in Nam Du, Hanoi Master thesis, Department of Geology Lund University

Lin, L., Yuan, S., Chen, J., Xu, Z., Lu, X., 2009. Removal of ammonia nitrogen in wastewater by microwave radiation. Journal of Hazardous Materials, 161, 1063-1068.

Lopes, E.C.N., Anjos, F.S.C.D., Vieira, E.F.S., Cestari, A.R., 2003. An alternative Avrami equation to evaluate kinetic parameters of the interaction of $\mathrm{Hg}(\mathrm{II})$ with thin chitosan membranes. Journal of Colloid and Interface Science 263 (2), 542-547.

Marañón, E., Ulmanu, M., Fernández, Y., Anger, I., Castrillón, L., 2006. Removal of ammonium from aqueous solutions with volcanic tuff. Journal of Hazardous Materials 137 (3), 1402-1409.

Moradi, O., 2011. The removal of ions by functionalized carbon nanotube: equilibrium, isotherms and thermodynamic studies. Chemical and Biochemical Engineering 25 (2), 229-240.

Moreno-Castilla, C., López-Ramón, M.V., Carrasco-Marín, F., 2000. Changes in surface chemistry of activated carbons by wet oxidation. Carbon 38 (14), 1995-2001.

Otal, E., Vilches, L.F., Luna, Y., Poblete, R., García-Maya, J.M., Fernández-Pereira, C., 2013. Ammonium ion adsorption and settleability improvement achieved in a synthetic zeolite-amended activated sludge. Chinese Journal of Chemical Engineering 21 (9), 1062-1068.

Rozic, M., Cerjan-Stefanovic, S., Kurajica, S., Vancina, V. and Hodzic,E,. 2000. Ammonical nitrogenremoval from waste treatment with lays and zeolites. Water Research, 34 (14), 3675-3681.

Soto-Garrido, G., Aguilar, C., García, R., Arriagada, R., 2003. A peach stone activatedcarbon chemically modified to adsorb aqueous ammonia. Journal of the Chilean Chemical Society 48 (3), 1-9.

Takashi, A., Takashi, O., Kuniaki, K., Kikuo, O., 2006. Ammonia adsorption on bamboo charcoal with acid treatment. Journal of Health Science 52 (5), 585-589.

Trinh, X.D., 2009. Research on modification of activate carbon to use as absortbent to remove ammonium and heavy metal from water. Masters thesis, VNU University of Science, Hanoi, Vietnam. 
Tseng, J.Y., Chang, C.Y., Chang, C.F., Chen, Y.H., Chang, C.C., Ji, D.R., Chiu, C.Y., Chiang, P.C., 2009. Kinetics and equilibrium of desorption removal of copper from magnetic polymer adsorbent. Journal of Hazardous Materials, 171 (1-3), 370-377.

Vassileva, P., Tzvetkova, R., Nickolov, R., 2008. Removal of ammonium ions from aqueous solutions with coal-based activated carbons modified by oxidation. Fuel 88 (2), 387390.

Vietnam Environment Agency, 2016. Vietnam's National Environment Report 2011-2015, Hanoi

WHO, Ammonia, http://www.who.int/water_sanitation_health/dwq/chemicals/ammoniasum.pdf, accessed 30.10 .16

Yahaya, N.K.E.M., Abustan, I., Latiff, M.F.P.M., Solomon Bello, O.S., Ahmad, M.A., 2011. Fixed-bed column study for $\mathrm{Cu}$ (II) removal from aqueous solutions using rice husk based activated carbon. International Journal of Engineering \& Technology, 11 (01), 186-190.

Zeng, Z., Zhang S.D., Li, T.Q., Zhao, F.L, He, Z.L., Zhao, H.P., Yang X., Hai-long W., Zhao H.L., Rafiq, M.T., 2013. Sorption of ammonium and phosphate from aqueous solution by biochar derived from phytoremediation plants. Journal of Zhejieng University Science 14 (12), 1152-1161.

Zhang, L.Y., Zhang, H.Y., Guo, W., Tian, Y.L., 2013. Sorption characteristics and mechanisms of ammonium by coal by-products: slag, honeycomb-cinder and coal gangue. International Journal of Environmental Science and Technology 10 (6), 13091318

Zhu, K., Fu H., Zhang J., Lv, X., Tang J., Xu X., 2012. Studies on removal of $\mathrm{NH}_{4}{ }^{+}-\mathrm{N}$ from aqueous solution by using the activated carbons derived from rice husk. Biomass and Bioenergy 43, 18-25. 